\title{
EFFECTS OF CERTAIN ORGANISMS ASSOCIATED WITH CHRONIC RESPIRATORY DISEASE ON SPF AND CON- VENTIONAL RATS
}

\author{
Deirdre P. Bell AND P. C. Elmes \\ Department of Therapeutics and Pharmacology, Queen's University, Belfast
}

Plates XXXV-XXXVII

LABORATORY rats are subject to a chronic respiratory disease (CRD) that is histologically similar to chronic bronchitis in man and can be detected from the early age of $5 \mathrm{wk}($ Bell, 1967). Experimental procedures and similar stresses cause the disease to increase, so that its presence may lead to serious misinterpretation of experimental results. Today, healthy specific-pathogen-free (SPF) rats free of this disease are widely available and there is seldom justification for using what is now termed " dirty" stock.

Nelson $(1946,1948)$ believed that CRD in rats is caused by a virus-like agent transmitted from mother to young soon after birth. He obtained from Professor Reyniers Caesareanderived rats that had been artificially reared in isolation and established an SPF colony free of CRD and other infectious diseases, including rhinitis and otitis media (Nelson, 1951).

But the precise nature of the causative agent of CRD in rats remains a subject of controversy. In addition to the " virus" hypothesis of Nelson, many bacteria have been associated with the disease, e.g., a " streptothrix" (Tunnicliff, 1916), Bacillus (Bordetella) bronchisepticus (Hoskins and Stout, 1919-20) and a pleomorphic organism resembling B. (Actinobacillus) actinoides (Jones, 1922). According to Nelson (1967), the "streptothrix" of Tunnicliff was Streptobacillus moniliformis, a highly pleomorphic organism described later by Klieneberger and Steabben (1937) and often accompanied by its variant " $L_{1}$ ".

Another organism " $\mathrm{L}_{3}$ " was isolated by Klieneberger and Steabben (1940) from the lungs and nasopharynx of many but not all rats with pathological evidence of CRD, but only rarely from rats of under a month old (Klieneberger-Nobel, 1962). The " $\mathbf{L}_{3}$ " organism is now referred to as Mycoplasma pulmonis and is apparently identical with the "coccobacilliform bodies" to which Nelson (1940) attributed infectious catarrh of rats (Edward, 1954; Nelson, 1967). When rats are subjected to bronchial ligation, $M$. pulmonis invades the lungs, multiplies rapidly and is recoverable from the bronchiectatic lesions, which develop within 12 days of the operation (Klieneberger-Nobel and Cheng, 1955). Serological studies by Lemcke (1961) provided further evidence of a relation between lesions of CRD and the presence of $M$. pulmonis in the lung. She found that the increase in antibody titre to $\mathrm{L}_{3}$ was correlated with isolation of the organism from the lungs and the extent of pathological damage.

Other workers have commented on the close structural similarity between the intracellular inclusions of CRD agent from rats (Vrolijk, Verlinde and Braams, 1957) and those of "grey lung virus" in mice as described by Andrewes and Glover (1945), Andrewes and Niven (1950) and Niven (1950). Gay and Attridge (1967) reported that the CRD agent resembled "grey lung virus" in its failure to grow in culture media, its failure to elicit immunity in infected animals and its sensitivity to chemotherapeutic substances in vivo. Gay (1967) showed by electron microscopy that in the mouse both these organisms appear

Received 31 Mar. 1969; accepted 16 May 1969.

J. MED. MICROBIOL.-VOL. 2 (1969) 
as complex membrane-bounded cytoplasmic inclusions within the large mononuclear cells present in the lumen of some respiratory bronchioles and alveoli, and resemble those described by Organick, Siegesmund and Lutsky (1966) in mice infected with M. pulmonis.

In the present study conventional and SPF rats were examined by cultural and serological techniques for evidence of $S$. moniliformis and $M$. pulmonis infection, and the results were compared with the histological findings.

A similar cultural, serological and histological investigation was made on SPF animals given cultures of $S$. moniliformis or $M$. pulmonis or mixtures of both, or lung homogenate, from a rat with CRD, known to contain both $S$. moniliformis and $M$. pulmonis.

SPF rats were given lung homogenate from a rat with CRD from which $S$. moniliformis and $M$. pulmonis could not be cultured. Cortisone was then given to see whether this affected the pathological changes produced.

\section{MATERIALS AND METHODS}

\section{Rats}

All of the rats were Wistar-derived and of one strain, but were kept in two separate colonies. The " conventional" colony was founded in 1959 and kept under conventional conditions. Animals of this colony were known to have spontaneous CRD, bartonellosis and several other infectious conditions common in ordinary laboratory rats. The SPF colony was founded in 1960 and has been maintained in isolation by a simple " barrier" technique (Wheeler, 1963; Bell, Elmes and Wheeler, 1964). Animals of this colony were free from CRD (fig. 1) and all infectious diseases (except pin-worm) that were present in the conventional colony (Bell, 1967, 1968). The original stock for both of these colonies was provided by Imperial Chemical Industries Ltd soon after they started an SPF rat colony (Davey, 1959). Both colonies were fed on the same diet and kept in similar cages.

\section{Bacteriology and serology}

Animals were killed with an overdose of sodium pentobarbitone by intraperitoneal injection. With aseptic technique $2 \mathrm{ml}$ or more of blood were removed from the heart while it was still beating and the serum was separated and stored at $-20^{\circ} \mathrm{C}$ for complementfixation tests to determine specific antibodies against $M$. pulmonis, $S$. moniliformis and $L_{1}$ in each rat. The culture and serum antibody techniques are described in detail by Gay (1968). The thorax was opened and the lungs removed aseptically, the right one for culture and the left for histology. A culture swab, consisting of a small pledget of wool on the end of a 3 -in. $(7 \cdot 5-\mathrm{cm})$ piece of thin wire, was inserted first through the external nares and then into the nasopharynx via the cut end of the trachea and plated on to blood agar. The right lung was ground and suspended in broth medium that contained inhibitors. Log dilutions were plated on standard and " B" agar plates, and inoculated into broth, and the cultures were inspected for growth of $S$. moniliformis and $M$. pulmonis. Mycoplasma growths were characterised by a central papilla in each colony indicating a region of growth lying below the surface of the agar.

\section{Histopathology}

Methods. The left lung was fixed in Carnoy's fluid, embedded and sectioned lengthwise to expose the bronchus and its branches. Sections were stained with haematoxylin and eosin, methyl green and pyronin, 0.05 per cent. toluidine blue and Weigert's elastin stain, and by the periodic acid-Schiff (PAS) method. They were examined for goblet cells, aspirated mucus, evidence of inflammation and pulmonary fibrosis.

In the third experiment, bacteriological and serological tests were not carried out and it was possible to kill the animals with chloroform and to fix the lungs by infusion of fixative 


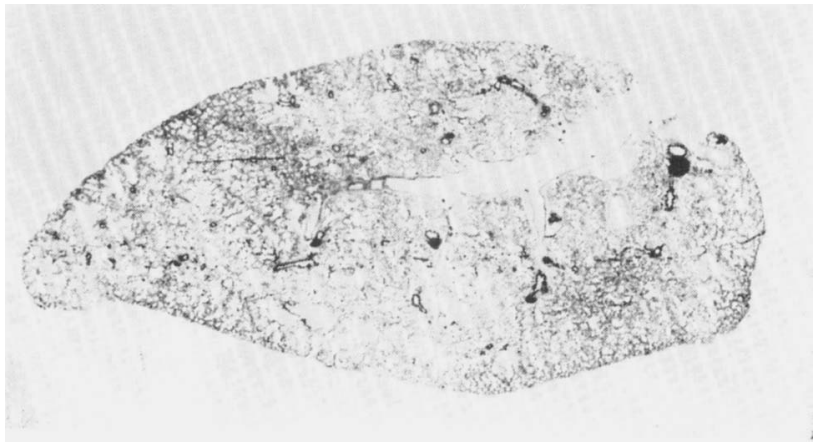

FIG. 1.--Left lung of SPF rat aged $10 \mathrm{mth}$ : no evidence of chronic respiratory disease (CRD). Haematoxylin and eosin. $\times 4$.
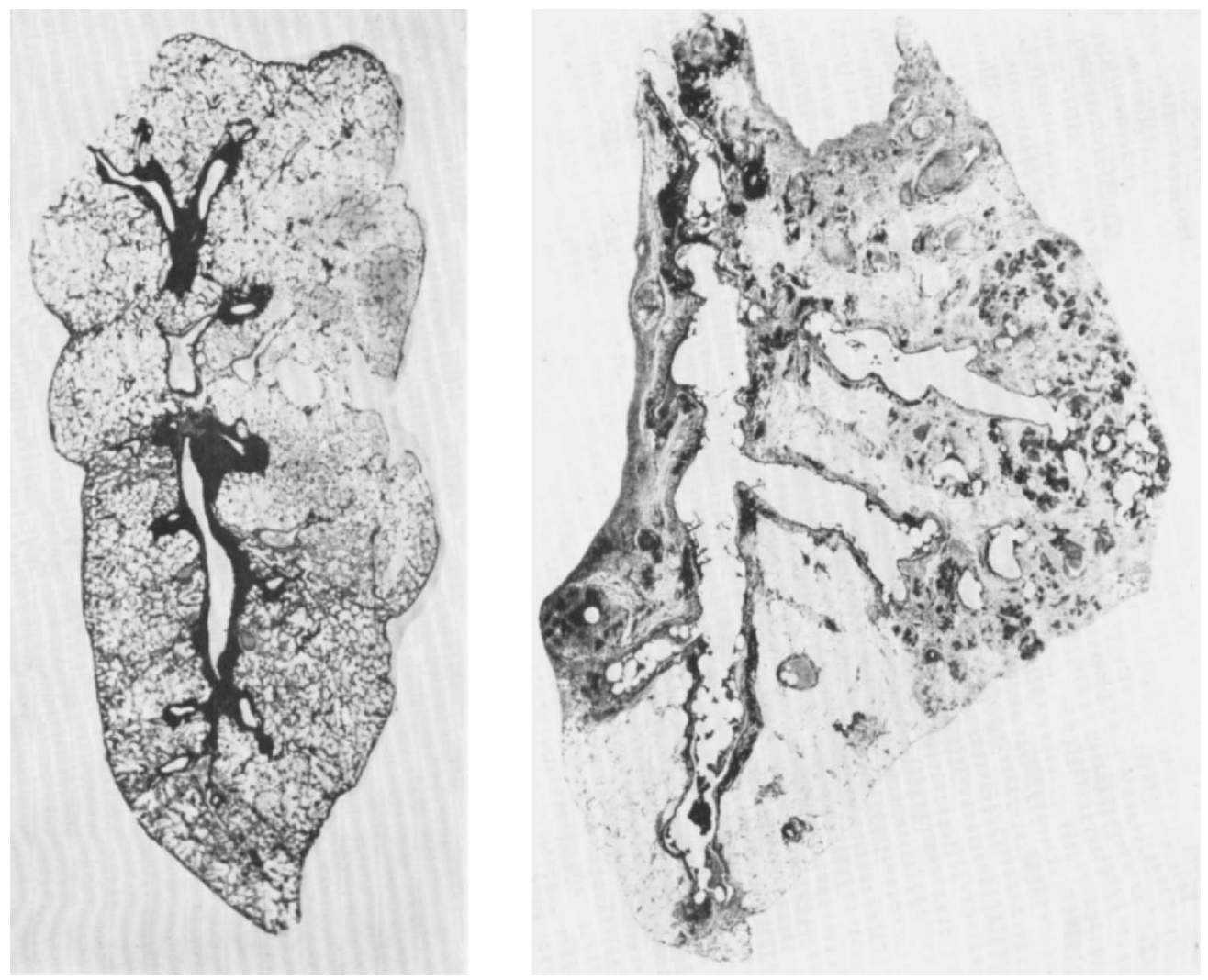

FIG. 2.-Left lung of two conventional rats aged $18 \mathrm{mth}$ : left moderate, right gross, lesions of CRD. HE. $\times 4$. 
INFECTIONS IN SPF AND CONVENTIONAL RATS

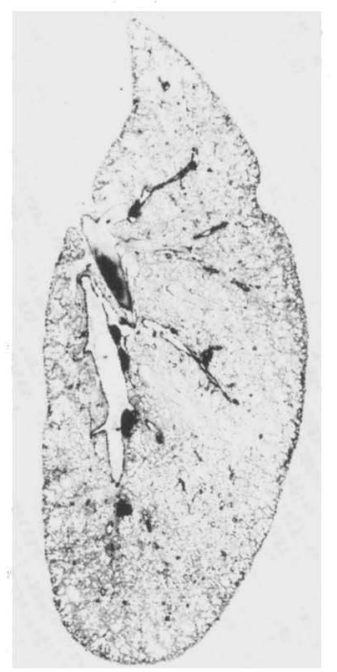

Fig. 3a.-Inoculation of sterile broth: CRD did not develop.

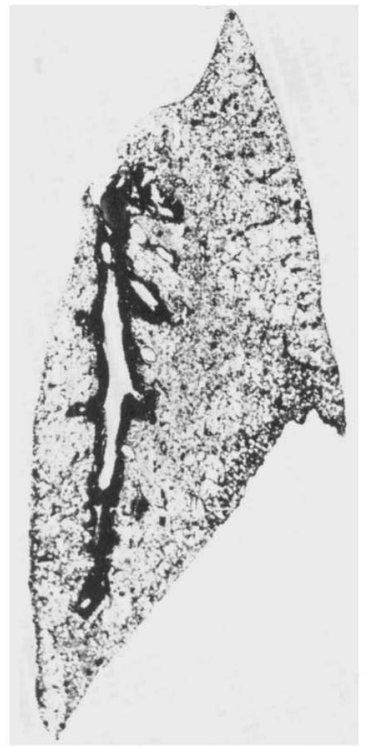

Fig. 3b.-Inoculation of lung homogenate from conventional rat with CRD: gross lesions of CRD.

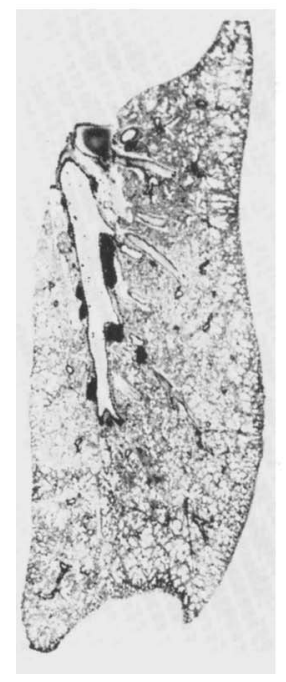

FIG. 3c.-Inoculation of Streptobacillus moniliformis: minor changes not attributable to CRD.

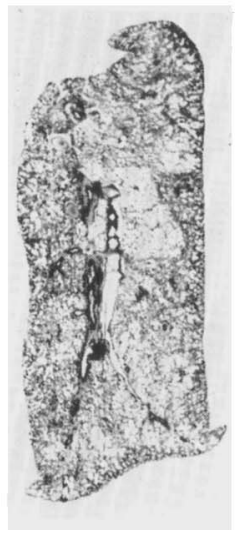

FIG. 3d.--Inoculation of Mycoplasma pulmonis: minor changes.

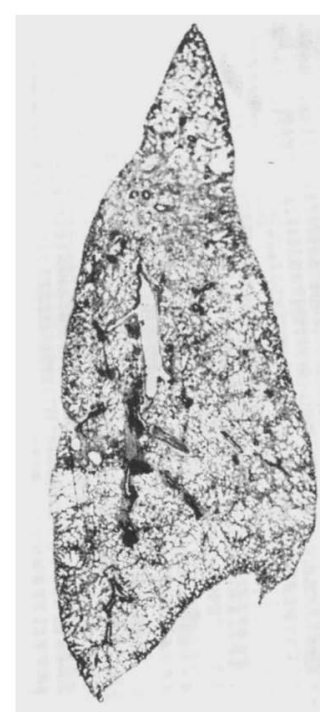

Fig. 3e.-Inoculation of $S$. moniliformis and $M$. pulmonis: minor changes.

Fig. 3.-Left lungs of SPF rats given an inoculation of various materials. HE. $\times 3$. 
INFECTIONS IN SPF AND CONVENTIONAL RATS

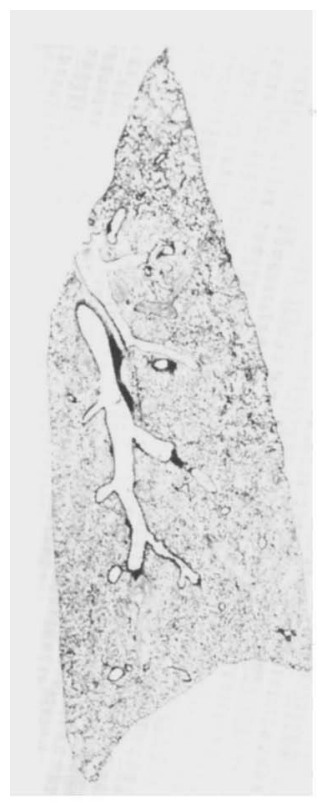

FIG. 4a.-Inoculation of sterile homogenate; no cortisone: normal lung.

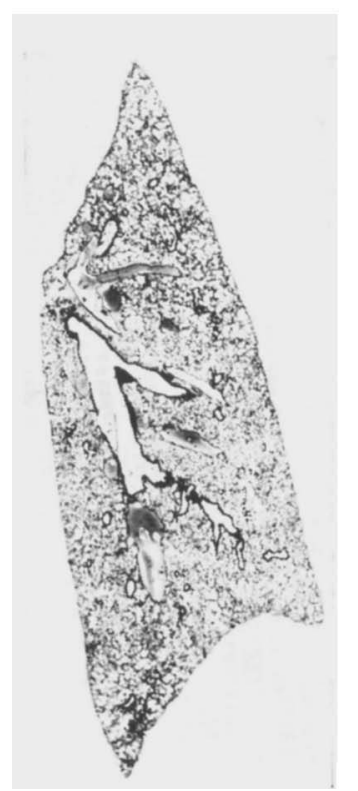

FIG. $4 c$.-Inoculation of sterile homogenate; cortisonetreated: normal lung.

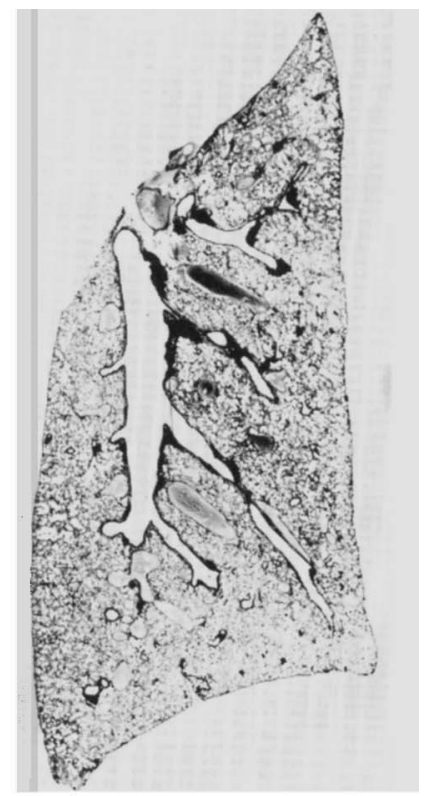

FIG. 4b.-Inoculation of CRD agent: well established CRD.

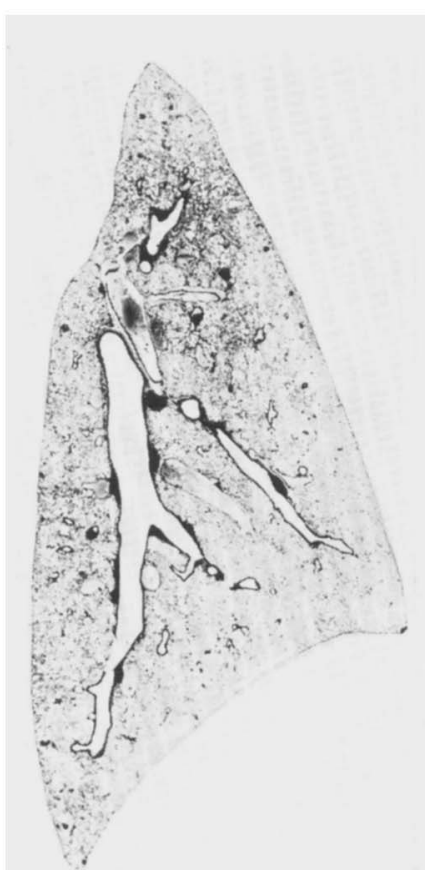

FIG. 4d.-Inoculation of CRD agent; cortisone-treated: well established CRD, similar to changes in fig. $4 b$.

FIG. 4. - Lungs of SPF rats given an inoculation of various substances. HE. $\times 3$. 
into the trachea (Elmes and Bell, 1963). The left lung was stained as for experiments 1 and 2, but analysed in more detail by a method used previously on a large group of SPF and conventional rats of various ages (Bell, 1967).

Grading. Three grades of histological change were distinguishable. Grade-I lungs were considered to be free of CRD. The lymphoid foci were small and discrete and contained no germinal foci. There was no perivascular or peribronchial lymphocytic cuffing, although in some cases the bronchial muscle was split by small collections of lymphocytes. Goblet cells were confined to the carinal areas of the main bronchus. Mucus, polymorphonuclear exudates and pneumonia were absent. Grade-II lungs showed hyperplasia of the lymphoid tissue around the main bronchus. Germinal centres were present in the lymph-nodes, and sometimes there was polypoid protrusion of lymphoid foci, covered by mucosa, into the bronchial lumen. Sometimes there was slight perivascular and peribronchial cuffing and proliferation of goblet cells, but no free or aspirated mucus and no pneumonia. Grade-III changes, recognised as gross CRD, were more severe than is usually found in conventional rats of the same age. The lymphoid foci were enlarged and with active germinal centres. Peribronchial and perivascular cuffing was present. Many bronchi were blocked with mucus, and aspiration of mucus into alveoli was sometimes accompanied by an acute inflammatory polymorph reaction. There was a marked proliferation of goblet cells (over 500 in most sections).

\section{Inoculation technique}

The animals were brought in sterile boxes to the inoculation cabinet, controls first. While the rat was under light ether anaesthesia 2-3 drops of inoculum were placed on its nostrils; most of the fluid was inhaled. Each group was then returned to its original room and the cabinet was sterilised between groups.

\section{EXPERIMENTS AND RESULTS \\ Experiment 1 \\ Identification of organisms}

Sixteen SPF and 16 conventional rats in 4 groups matched for age, ranging from 3 to $18 \mathrm{mth}$ old (table I) were used to determine the natural distribution of $S$. moniliformis and $M$. pulmonis in nasopharynx and lungs in relation to the antibody titres to these organisms and to $\mathrm{L}_{1}$, and to the histological changes in the lung.

\section{Results}

$S P F$ rats (table I). Lung and nasopharyngeal cultures were negative for $S$. moniliformis and $M$. pulmonis in every rat regardless of age. Complementfixation tests gave low titres $(<4)$ against $S$. moniliformis, $\mathrm{L}_{1}$ and $M$. pulmonis. Lung histology was within normal limits according to criteria of normality established by an earlier study (Bell, 1967) and there was no evidence of CRD in any of the lungs (fig. 1).

Conventional rats (table I). Lung and nasopharyngeal cultures were almost all negative in the 3-mth-old group, but many of the older rats yielded positive cultures of both $S$. moniliformis and $M$. pulmonis from either or both sites. Cultures from the nasopharynx were more often positive than those from the lung. In some cases, the lung and nasopharynx yielded growths of $M$. pulmonis without $S$. moniliformis. The antibody titres against $S$. moniliformis reached significant levels (16-256) in most of the rats. This was true to a lesser extent for antibodies against $\mathrm{L}_{1}$, but antibodies against $M$. pulmonis were of relatively 
TABLE I

Relations between cultural, antibody and histological findings in SPF rats and rats with chronic respiratory disease

\begin{tabular}{|c|c|c|c|c|c|c|c|c|c|c|}
\hline \multirow{3}{*}{ Rats } & \multirow{3}{*}{$\begin{array}{c}\text { Age } \\
(\mathrm{mth})\end{array}$} & \multirow{3}{*}{$\begin{array}{l}\text { Rat } \\
\text { code } \\
\text { no. }\end{array}$} & \multicolumn{4}{|c|}{ Cultures } & \multirow{2}{*}{\multicolumn{3}{|c|}{$\begin{array}{l}\text { Complement-fixation } \\
\text { titre of rat serum } \\
\text { against }\end{array}$}} & \multirow{3}{*}{$\begin{array}{l}\text { Lung } \\
\text { histo- } \\
\text { pathology } \\
\text { grade } \\
\text { (see text) }\end{array}$} \\
\hline & & & \multicolumn{2}{|c|}{ Lung } & \multicolumn{2}{|c|}{ Nasopharynx } & & & & \\
\hline & & & $\begin{array}{l}\text { S. monili- } \\
\text { formis }\end{array}$ & $\begin{array}{c}\text { M. } \\
\text { pulmonis }\end{array}$ & $\begin{array}{l}\text { S. monili- } \\
\text { formis }\end{array}$ & $\begin{array}{c}\text { M. } \\
\text { pulmonis }\end{array}$ & $\begin{array}{l}\text { S. monili- } \\
\text { formis }\end{array}$ & $\mathrm{L}_{1}$ & $\begin{array}{c}M . \\
\text { pulmonis }\end{array}$ & \\
\hline \multirow[t]{4}{*}{ SPF } & 3 & $\begin{array}{l}715 \\
800 \\
802 \\
944\end{array}$ & $\begin{array}{l}- \\
= \\
=\end{array}$ & $\begin{array}{l}- \\
z \\
-\end{array}$ & $\begin{array}{l}- \\
- \\
-\end{array}$ & $\begin{array}{l}- \\
\overline{-} \\
-\end{array}$ & $\begin{array}{l}<4 \\
<4 \\
<4 \\
<4\end{array}$ & $\begin{array}{l}<4 \\
<4 \\
<4 \\
<4\end{array}$ & $\begin{array}{l}<4 \\
<4 \\
<4 \\
<4\end{array}$ & $\begin{array}{l}\text { I } \\
\text { I } \\
\text { I } \\
\text { I }\end{array}$ \\
\hline & 7 & $\begin{array}{l}713 \\
716 \\
801 \\
945\end{array}$ & $\begin{array}{l}z \\
z\end{array}$ & $\begin{array}{l}\bar{z} \\
\overline{-}\end{array}$ & $\begin{array}{l}- \\
\overline{-} \\
-\end{array}$ & $\begin{array}{l}- \\
\overline{-} \\
-\end{array}$ & $\begin{array}{l}<4 \\
<4 \\
<4 \\
<4\end{array}$ & $\begin{array}{l}<4 \\
<4 \\
<4 \\
<4\end{array}$ & $\begin{array}{l}<4 \\
<4 \\
<4 \\
<4\end{array}$ & $\begin{array}{l}\text { I } \\
\text { I } \\
\mathbf{I} \\
\text { I }\end{array}$ \\
\hline & 10 & $\begin{array}{l}786 \\
787 \\
788 \\
789\end{array}$ & $\begin{array}{l}\overline{-} \\
\bar{z}\end{array}$ & $\begin{array}{l}\overline{-} \\
\bar{z} \\
-\end{array}$ & $\begin{array}{l}- \\
- \\
-\end{array}$ & $\begin{array}{l}\overline{-} \\
\bar{z}\end{array}$ & $\begin{array}{l}<4 \\
<4 \\
<4 \\
<4\end{array}$ & $\begin{array}{l}<4 \\
<4 \\
<4 \\
<4\end{array}$ & $\begin{array}{l}<4 \\
<4 \\
<4 \\
<4\end{array}$ & $\begin{array}{l}\text { I } \\
\text { II } \\
\text { I } \\
\text { II }\end{array}$ \\
\hline & 18 & $\begin{array}{l}946 \\
971 \\
976 \\
943\end{array}$ & $\begin{array}{l}- \\
- \\
-\end{array}$ & $\begin{array}{l}- \\
- \\
-\end{array}$ & $\begin{array}{l}- \\
\overline{-} \\
=\end{array}$ & $\begin{array}{l}- \\
z \\
-\end{array}$ & $\begin{array}{l}<4 \\
<4 \\
<4 \\
<4\end{array}$ & $\begin{array}{l}<4 \\
<4 \\
<4 \\
<4\end{array}$ & $\begin{array}{l}<4 \\
<4 \\
<4 \\
<4\end{array}$ & $\begin{array}{l}\text { I } \\
\text { I } \\
\text { I } \\
\text { I }\end{array}$ \\
\hline \multirow[t]{4}{*}{ CRD } & 3 & $\begin{array}{l}803 \\
806 \\
807 \\
808\end{array}$ & $\begin{array}{l}z \\
- \\
-\end{array}$ & $\begin{array}{l}- \\
- \\
-\end{array}$ & $\begin{array}{l}- \\
= \\
-\end{array}$ & $\begin{array}{l}- \\
\overline{+}\end{array}$ & $\begin{array}{r}32 \\
128 \\
128 \\
32\end{array}$ & $\begin{array}{r}<4 \\
<4 \\
<4 \\
256\end{array}$ & $\begin{array}{r}<4 \\
<4 \\
<4 \\
4\end{array}$ & $\underset{\text { II }}{\text { III }}$ \\
\hline & 7 & $\begin{array}{l}805 \\
895 \\
896 \\
897\end{array}$ & $\begin{array}{l}\overline{+} \\
- \\
-\end{array}$ & $\bar{I}$ & $\begin{array}{l} \pm \\
\pm \\
-\end{array}$ & $\begin{array}{l}- \\
+ \\
+ \\
+\end{array}$ & $\begin{array}{l}64 \\
16 \\
16 \\
32\end{array}$ & $\begin{array}{r}64 \\
64 \\
8 \\
32\end{array}$ & $\begin{array}{r}<4 \\
8 \\
<4 \\
<4\end{array}$ & $\begin{array}{l}\text { III } \\
\text { III } \\
\text { III } \\
\text { III }\end{array}$ \\
\hline & 10 & $\begin{array}{l}868 \\
869 \\
870 \\
888\end{array}$ & $\frac{+}{+}$ & $\begin{array}{l} \pm \\
+ \\
+\end{array}$ & $\begin{array}{l}+ \\
+ \\
+ \\
+\end{array}$ & $\begin{array}{l}+ \\
+ \\
+\end{array}$ & $\begin{array}{r}256 \\
32 \\
8 \\
128\end{array}$ & $\begin{array}{r}64 \\
32 \\
8 \\
128\end{array}$ & $\begin{array}{r}8 \\
<4 \\
<4 \\
16\end{array}$ & $\begin{array}{l}\text { III } \\
\text { III } \\
\text { III } \\
\text { III }\end{array}$ \\
\hline & 18 & $\begin{array}{l}714 \\
810 \\
816 \\
817\end{array}$ & $\begin{array}{l} \pm \\
- \\
-\end{array}$ & $\begin{array}{l}+ \\
+ \\
+\end{array}$ & $\begin{array}{l}\dddot{+} \\
+ \\
+\end{array}$ & $\begin{array}{l}\ldots \\
+ \\
+ \\
+\end{array}$ & $\begin{array}{l}\mathrm{AC}^{*} \\
<4 \\
\mathrm{AC} \\
64\end{array}$ & $\begin{array}{r}\mathrm{AC} \\
<4 \\
\mathrm{AC} \\
16\end{array}$ & $\begin{array}{c}\mathrm{AC} \\
<4 \\
\mathrm{AC} \\
<4\end{array}$ & $\begin{array}{l}\text { III } \\
\text { III } \\
\text { III } \\
\text { III }\end{array}$ \\
\hline
\end{tabular}

${ }^{*} \mathrm{AC}=$ Serum anticomplementary. 
low titre. Histological examination of the left lung showed definite evidence of CRD in all except one of the lungs and the disease tended to be severe in the older animals (fig. 2).

\section{Experiment 2 \\ Inoculation studies}

Forty-five SPF weanling rats making up 6 litters were randomly allocated to 5 inoculation groups (A-E, table II). Each group (8-10 rats) was placed in a separate room where it was kept in isolation from other animals for the duration of the experiment. Thorough hand-washing was carried out in each room before attending to the animals, which were handled as little as possible. Cages, bedding and other equipment were autoclaved before use and a commercially autoclaved diet was used. Daily care of the animals began with the controls and ended with group B. No other precautions were thought necessary to prevent cross-infection between groups. Each group was given an inoculation at 4 wk old, group $\mathrm{A}$ of standard sterile broth, group $\mathrm{C}$ of a 3-day broth culture of $S$. moniliformis $\left(1.8 \times 10^{6}\right.$ c.f.u. per ml), group D of a 6-day broth culture of $M$. pulmonis $\left(6.0 \times 10^{6}\right.$ c.f.u. per $\left.\mathrm{ml}\right)$, group $\mathrm{E}$ of broth containing a mixture of $S$. moniliformis and $M$. pulmonis and group B of a 20 per cent. lung homogenate, containing $S$. moniliformis and $M$. pulmonis, from an 18-mth-old conventional rat. During the course of the experiment, two females in group C became pregnant. They were allowed to rear their litters, which shared cages with group-C rats throughout the experiment but were not given any inoculation. Antibody and histopathology assessments were made of this additional group $\left(\mathrm{C}_{1}\right)$. The inoculated rats were killed for examination at $10 \mathrm{mth}$ and the $\mathrm{C}_{1}$ group at $7 \mathrm{mth}$.

\section{RESULTS}

Bacteriology and serology (table II). A positive culture of M. pulmonis was obtained from one rat in group B, but many of the nasopharyngeal cultures were contaminated with a profuse growth of $B$. proteus, which made identification of the other organisms impossible; the results were discarded.

Low serum antibody titres against $S$. moniliformis were found in group A (sterile broth), group B (lung homogenate) and group D (M. pulmonis), but in groups $\mathrm{C}$ and $\mathrm{E}$, which had been specifically given an inoculation of $S$. moniliformis, the titres were considerably above the level attributable to nonspecific fixation and experimental error (table II). Group $C_{1}$ also had as high titres as group $\mathrm{C}$, indicating that $S$. moniliformis had been effectively transmitted to them by direct contact with their parents.

In contrast, the titres to $M$. pulmonis were low and were found in only 5 animals, 3 of which were in group E. In group A the titres were uniformly low $(<4)$. Three of the complement-fixation tests in group B and one in group D failed because the serum was anticomplementary.

Histopathology (table II). The rats in group A, which were given an inoculation of sterile broth all had lung changes in grade I (fig. $3 a$ ), except one with grade-II changes. 
In contrast, all of the animals in group $B$, which were given an inoculation of lung homogenate, had grade-III lung changes (fig. $3 b$ ).

The changes found in animals in group $\mathrm{C}$ (given an inoculation of $S$. moniliformis), their progeny (group $\mathrm{C}_{1}$ ), group $\mathrm{D}(M$. pulmonis) and group $\mathrm{E}$ (S. moniliformis and $M$. pulmonis) were not significantly different from those found in the animals in group A. Nine were grade II, the rest grade I (fig. $3 c$, $d$ and $e$ ).

TABLE II

The effects of various inocula on the lung histology and antibody titres of SPF rats

\begin{tabular}{|c|c|c|c|c|c|c|c|c|c|}
\hline \multirow{4}{*}{ Group } & \multirow{4}{*}{$\begin{array}{l}\text { Number } \\
\text { of } \\
\text { animals }\end{array}$} & \multirow{4}{*}{ Inoculum } & \multicolumn{7}{|c|}{ Number of animals in each group showing } \\
\hline & & & \multirow{2}{*}{\multicolumn{3}{|c|}{$\begin{array}{l}\text { lung histopathology } \\
\text { grade }\end{array}$}} & \multicolumn{4}{|c|}{ serum antibody titres against } \\
\hline & & & & & & \multicolumn{2}{|c|}{ S. moniliformis } & \multicolumn{2}{|c|}{ M. pulmonis } \\
\hline & & & $\mathbf{I}$ & II & III & $<8$ & $\geqq 8$ & $<8$ & $\geqq 8$ \\
\hline $\begin{array}{l}\mathbf{A} \\
\mathbf{B}\end{array}$ & $\begin{array}{l}9 \\
8\end{array}$ & $\begin{array}{l}\text { Sterile broth } \\
\text { Infected lung homo- } \\
\text { genate }\end{array}$ & $\begin{array}{l}8 \\
0\end{array}$ & $\begin{array}{l}1 \\
0\end{array}$ & $\begin{array}{l}0 \\
8\end{array}$ & 7 & $\begin{array}{l}2^{*} \\
0\end{array}$ & $\stackrel{9}{5 \dagger}$ & $\begin{array}{l}0 \\
0\end{array}$ \\
\hline $\begin{array}{l}\mathrm{C} \\
\mathrm{C}_{1}\end{array}$ & $\begin{array}{l}9 \\
9\end{array}$ & $\begin{array}{l}\text { S. moniliformis culture } \\
\text { Not inoculated but } \\
\text { offspring of C after } \\
\text { inoculation }\end{array}$ & $\begin{array}{l}9 \\
7\end{array}$ & $\begin{array}{l}0 \\
2\end{array}$ & $\begin{array}{l}0 \\
0\end{array}$ & $\begin{array}{l}0 \\
0\end{array}$ & & $\begin{array}{l}9 \\
9\end{array}$ & $\begin{array}{l}0 \\
0\end{array}$ \\
\hline$\stackrel{\mathbf{D}}{\mathbf{E}}$ & $\begin{array}{r}9 \\
10\end{array}$ & $\begin{array}{l}M . \text { pulmonis culture } \\
\text { Mixture of } S \text {. monili- } \\
\text { formis and } M . \text { pul- } \\
\text { monis cultures }\end{array}$ & $\begin{array}{l}6 \\
6\end{array}$ & $\begin{array}{l}3 \\
4\end{array}$ & $\begin{array}{l}0 \\
0\end{array}$ & $\begin{array}{l}7 \dagger \\
0\end{array}$ & $10^{1 *}$ & $\begin{array}{l}8 \dagger \\
9\end{array}$ & $\begin{array}{l}0 \\
1^{*}\end{array}$ \\
\hline
\end{tabular}

* Titres of 16 or less; † remainder anticomplementary; $\ddagger$ all titres of 64 or over.

\section{Experiment 3}

\section{Cortisone treatment}

Three animal rooms were fumigated with formalin vapour. Seventeen pregnant SPF rats were then transferred into them, 5 or 6 per room, a few days before their litters were due. At 10 days old, the young in rooms 1 and 2 (97) were given an intranasal inoculation of lung homogenate from the lung of a CRD rat from which $S$. moniliformis and $M$. pulmonis could not be cultured. The 46 young rats in room 3 were given an inoculation of sterilised lung suspension, as controls. Two days after inoculation a 3-wk course of cortisone treatment was given by a single daily intraperitoneal injection $(15 \mathrm{mg}$ per $\mathrm{kg})$ to half of the rats in each room, i.e., 48 of those given the CRD agent and 23 of the controls (table III). Throughout the experiment the same precautions were taken as in experiment 2 to prevent cross-infection between the infected animals and the controls. The young rats were weaned at 25 days. They were killed at $6 \mathrm{mth}$ old, and the left lung was examined histologically. Bacteriological and serological tests were omitted because of shortage of laboratory facilities. 


\section{RESULTS}

Animals not given cortisone. The lungs of SPF rats given an inoculation of homogenised lung from a diseased rat had well-developed changes of CRD. SPF rats given an inoculation of sterilised lung homogenate had only minor changes (fig. $4 a$ and $b$ ). Most of the histological features show a highly significant difference between the two groups (table III).

TABLE III

Effects of cortisone treatment on the lung histology of SPF rats after inoculation of CRD agent

\begin{tabular}{|c|c|c|c|c|c|c|}
\hline \multirow{2}{*}{ Change } & \multicolumn{2}{|c|}{$\begin{array}{l}\text { Number (and percentage) } \\
\text { of rats not treated with } \\
\text { cortisone showing this } \\
\text { change out of }\end{array}$} & \multirow{2}{*}{$\begin{array}{c}\mathrm{P} \text { for } \chi^{2} \text { test } \\
\text { between } \\
\mathrm{A} \text { and } \mathrm{B}\end{array}$} & \multicolumn{2}{|c|}{$\begin{array}{l}\text { Number (and percentage) } \\
\text { of rats treated with } \\
\text { cortisone showing this } \\
\text { change out of }\end{array}$} & \multirow{2}{*}{$\begin{array}{l}\mathbf{P} \text { for } \chi^{2} \text { test } \\
\text { between } \\
\mathbf{C} \text { and } \mathbf{D}\end{array}$} \\
\hline & $\begin{array}{l}23 \text { treated } \\
\text { with sterile } \\
\text { broth (A) }\end{array}$ & $\begin{array}{l}49 \text { treated } \\
\text { with CRD } \\
\text { agent (B) }\end{array}$ & & $\begin{array}{l}23 \text { treated } \\
\text { with sterile } \\
\text { broth (C) }\end{array}$ & $\begin{array}{l}48 \text { treated } \\
\text { with } C R D \\
\text { agent (D) }\end{array}$ & \\
\hline $\begin{array}{l}\text { Goblet cells }>500^{*} \\
\text { Lymph-nodes }>6^{*} \\
\text { Germinal centres } \\
\text { Peribronchial cuffing } \\
\text { Perivascular cuffing } \\
\text { Plasma cells }>300^{*}\end{array}$ & $\begin{array}{r}2(8 \cdot 7) \\
13(56 \cdot 5) \\
12(52 \cdot 2) \\
11(47 \cdot 8) \\
7(30 \cdot 4) \\
2(8 \cdot 7)\end{array}$ & $\begin{array}{ll}20 \dagger & (40 \cdot 8) \\
47 & (95 \cdot 9) \\
45 & (91 \cdot 8) \\
49 & (100) \\
49 & (100) \\
48 & (98 \cdot 0)\end{array}$ & $\begin{array}{l}<0.01 \\
<0.001 \\
<0.001 \\
<0.001 \\
<0.001 \\
<0.001\end{array}$ & $\begin{array}{r}1(4 \cdot 3) \\
11(47 \cdot 8) \\
7(30 \cdot 4) \\
8(34 \cdot 8) \\
8(34 \cdot 8) \\
3(13 \cdot 0)\end{array}$ & $\begin{array}{ll}33 \dagger(68 \cdot 8) \\
44 & (91 \cdot 7) \\
43 & (89 \cdot 6) \\
43 & (89 \cdot 6) \\
44 & (91 \cdot 7) \\
42 & (87 \cdot 5)\end{array}$ & $\begin{array}{l}<0.001 \\
<0.001 \\
<0.001 \\
<0.001 \\
<0.001 \\
<0.001\end{array}$ \\
\hline
\end{tabular}

* Per entire $5 \mu \mathrm{m}$-thick whole-lung section.

$\dagger$ These figures are significantly different $(P<0 \cdot 01)$.

The changes in the following were minor; none was significant: PAS-positive granules, pus cells in bronchi, mucus in bronchi, mucus in alveoli, arteriolar muscle hypertrophy, gaps in mucosa.

Animals given cortisone. The animals given an inoculation of sterile homogenate were the same, whether given cortisone or not. In the animals given active homogenate, cortisone did seem to modify the response a little (fig. $4 c$ and $d$, and table III). There was certainly a greater proliferation of goblet cells and an increase in mucus secretion. There seemed to be less plasma cell and lymphocyte proliferation, but these differences were not statistically significant.

\section{Discussion}

The first investigation showed that there was no bacteriological, serological or histopathological evidence of chronic respiratory disease (CRD) in the specific-pathogen-free (SPF) rats.

All the rats kept under conventional conditions had marked histological evidence of CRD. Most of them had serological evidence of infection with $S$. moniliformis and many of them of infection with its $\mathrm{L}_{1}$ variant. Serological evidence of $M$. pulmonis was seldom detected even when its presence had been confirmed by culture.

In this small study there was no apparent correlation between high titre 
levels or positive culture of either organism and the severity of histopathological change. It was impossible to conclude that these organisms cause CRD.

It is clear that infections by $S$. moniliformis and by $M$. pulmonis are not detected equally easily by complement fixation, which is unfortunate because this method of detection, if reliable, could be used in living animals. The low antibody response to the presence of $M$. pulmonis may indicate that the organism is a harmless commensal, or it may indicate that because antibody response is poor the organism may be a more serious infecting agent than is $S$. moniliformis.

The second investigation showed how easily CRD can be transmitted to SPF rats by inoculation with homogenised lung from a diseased rat. Rats so treated had insignificant antibody titres to $S$. moniliformis and $M$. pulmonis, and in only one animal was there a positive culture of either organism. These findings suggest that these organisms do not play an important role in the aetiology of CRD. This conclusion was confirmed by the absence of histological evidence of CRD in animals given an inoculation of cultures of $S$. moniliformis, of M. pulmonis or of a mixture of the two organisms.

The third investigation showed that cortisone administration made little difference to the development of CRD; this may be interpreted to mean that there is little antibody protection against CRD in SPF rats. Previously cortisone has produced a marked exacerbation of CRD in naturally infected rats (Bell et al., 1964). Since CRD was produced by an inoculum from which $S$. moniliformis and $M$. pulmonis could not be cultured, it appears that $S$. moniliformis and $M$. pulmonis are merely secondary invaders or possibly commensals.

\section{SUMMARY}

Most of a series of 16 conventional rats examined at various ages were found to have Streptobacillus moniliformis and Mycoplasma pulmonis in the nasopharynx and sometimes also in the lungs. Fifteen of the rats had histological evidence of chronic respiratory disease (CRD). Specific-pathogen-free (SPF) rats of the same strain, but kept in isolation, did not appear to carry these infections and had no histological evidence of CRD.

It was not possible to produce CRD in SPF rats by the intranasal inoculation of S. moniliformis, M. pulmonis or a mixture of the two. In contrast with this, lung homogenate from a naturally infected rat readily produced gross lesions of CRD in SPF rats, but the antibody titres to S. moniliformis and M. pulmonis remained low. The rats that had been given an inoculation of $S$. moniliformis showed little evidence of CRD, but had high antibody titres, and antibodies to the streptobacillus appeared in their progeny, which were in direct contact with their infected parents during a period of $7 \mathrm{mth}$. Inoculation of $M$. pulmonis failed to produce a significant antibody response.

Cortisone treatment of SPF rats given an inoculation of CRD agent without $S$. moniliformis and $M$. pulmonis promoted goblet-cell proliferation, but otherwise did not activate CRD. As cortisone activates CRD in naturally infected non-SPF rats, these findings suggest that the antibody response mechanism of SPF rats may be different from that of conventional rats. 
Our findings suggest that neither $S$. moniliformis nor $M$. pulmonis plays an important part in the causation of CRD; the causal agent in the infective lung homogenate was not identified.

We are indebted to Professor G. W. A. Dick and Dr D. M. S. Dane who supervised the bacteriological and serological investigations, which were carried out by Dr F. W. Gay. Miss Sylvia M. Wheeler and Miss E. A. Stevenson assisted with the pathological work. The foundation stock for the conventional and SPF colonies was kindly supplied by $\operatorname{Dr} D$. G. Davey of I.C.I., Alderley Park. The photographs were reproduced by the Department of Medical Photography, Queen's University.

\section{REFERENCES}

ANDRewes, C. H., AND Glover, R. E. . 1945. ANDrewes, C. H., AND Niven, JANEt S. F. 1950. Bell, Deirdre P. . . . . . . . 1967.

" . . . . . . . . . 1968.

Bell, Deirdre P., Elmes, P. C., ANd 1964. WheEler, Sylvia M.

DAVEY, D. G. . . . . . . . . 1959.

EDWARD, D. G. FF.. . . . . . . . . 1954.

Elmes, P. C., ANd Bell, Deirdre P. 1963.

GAY, F. W. . . . . . . . . . . . 1967.

, . . . . . . . . . . . 1968.

Gay, F. W., ANd Attridge, J. T. . 1967.

Hoskins, H. P., and Stout, Alice L. . 1919-20. J. Lab. Clin. Med., 5, 307.

JONES, F. S. . . . . . . . . . . . . . . 1922.

Klieneberger, EMmy, aND SteabBen, 1937.

DOROTHY B.

$\begin{array}{lll}\text { KLIENEBERGER-NOBEL, EMMY . . . . . . } 1940 . & 1962 .\end{array}$

KLIENEBERGER-NOBEL, EMMY, AND CHENG, 1955. K.K.

LEMCKE, RUTH M. . . . . . . . 1961.

Nelson, J. B. $\quad . \quad$. $\quad . \quad$. $\quad . \quad$. $\quad . \quad$. 1940.

, . . . . . . . . . 1946

, $\quad . \quad . \quad . \quad . \quad . \quad . \quad . \quad .61948$.

, . . . . . . . . 1951.

,

Niven, JANet S. F.

Organick, A. B., Stegesmund, K. A., AND LUTSKY, I. I.

TUNNICLIFF, RUTH .

WHEELER, SYLVIA M. . . . . . . . . . . $\quad$.

VroliJk, H., Verlinde, J. D., AND 1957. BraAMS, W. G.
Br. J. Exp. Path., 26, 379.

Ibid., 31, 767.

Lab. Anim., 1, 159.

Ibid., $2,1$.

Nature, Lond., 201, 273.

Lab. Anim. Cent. Coll. Pap., 8, 17.

J. Gen. Microbiol., 10, 27.

J. Path. Bact., 86, 317.

J. Bact., 94, 2048.

Ph.D. Thesis, Univ. Belfast.

J. Cell Sci., 2, 445.

J. Exp. Med., 35, 361.

J. Hyg., Camb., 37, 143.

Ibid., 40, 223.

Pleuropneumonia-like organisms (PPLO). Mycoplasmataceae, London, p. 118.

J. Path. Bact., 70, 245.

J. Hyg., Camb., 59, 401.

J. Exp. Med., 72, 655.

Ibid., 84, 15.

Ibid., 87, 11.

Ibid., 94, 377.

In Pathology of laboratory rats and mice, ed. by E. Cotchin and F. J. C. Roe, Oxford and Edinburgh, pp. 259-289.

1950. Br. J. Exp. Path., 31, 759.

1966. J. Bact., 92, 1164.

1916. J. Infect. Dis., 19, 767.

1963. J. Anim. Techns Assoc., 14, 23.

Antonie van Leeuwenhoek, 23, 173. 